\title{
Moral Education - The Wind Vane for College Teachers to Carry out Curriculum Ideology and Politics
}

\author{
Xiaoli Zhang*, Mengqi Zhang, Meng Li, Mei Song \\ College of Information and Communication, National University of Defense Technology, Xi'an 710106, China \\ *Corresponding author: Xiaoli Zhang, 995642922@qq.com
}

\begin{abstract}
Moral education is the fundamental task of education. It does not only include the inheritance of the fine traditional thoughts of the Chinese nation, but also the deepening of the new era of education concept with the new development in this changing world. Moral education has been widely implemented in the practical education process of colleges and universities and has achieved some outstanding results, but there are still some areas to be improved. Teachers in colleges and universities are the key to implement the concept of moral education, and classroom teaching is the main channel for the implementation of moral education. Therefore, teachers in colleges and universities need to deeply understand the essence and connotation of moral education, accurately grasp the practical problems existing in moral education, focus on the curriculum construction and the main channel of the classroom, and make every effort to exercise curriculum ideology and politics.
\end{abstract}

Keywords: Moral education; College teachers; Curriculum ideology and politics

Publication date: November 2021; Online publication: November 30, 2021

\section{Introduction}

At the 19th National Congress of the Communist Party of China, Chairman Xi delivered a report stating, "We must fully implement the Party's education policy, fulfil the fundamental task of fostering moral integrity and educating people, develop quality-oriented education, promote fairness in education, as well as train socialist builders and successors who are well developed morally, intellectually, physically, and aesthetically." Training people is the fundamental purpose of education. In the process of practical education, many teachers have integrated curriculum ideology and politics into the curriculum through practice and realized the integration of morality and knowledge. Morality and knowledge constitute the coordinate system of life, where moral quality is like the horizontal coordinate, knowledge level is like the vertical coordinate, and the starting point of life is the zero coordinate. If a person has bad moral quality but blessed with abundant knowledge, the more rebellious that person would be and the more destructive that individual would be to the society. Recognized talents must be those who contribute to the development of human society. Therefore, an individual is not considered a talent without a healthy moral quality, no matter how much knowledge he or she has. At the 2016 National Conference on Ideological and Political Work in Colleges and Universities, General Secretary Xi Jinping emphasized that "moral education should be taken as the central link while ideological and political work should be carried through the whole process of education and teaching, so as to realize the whole process and an all-round education as well as strive to create a new situation in the development of China's higher education [1]." Curriculum ideological and political education is mainly to integrate ideological and political education contents, including theoretical knowledge, values, and spiritual pursuit, into the curriculum, imperceptibly influence students' ideological 
consciousness and behavior, as well as enhance students' sense of mission and responsibility to the country, nation, and society ${ }^{[2]}$. As colleges and universities are at the forefront of cultivating talents in this new century, it is extremely urgent to implement moral cultivation in colleges and universities. Therefore, how would college teachers take advantage of the classroom as the main channel in the actual teaching process as well as exercise the idea of virtue and cultivating people?

\section{The essence and connotation of moral education based on higher education institutions}

Yunrong Cui and Shuangye Chen, two professors at the Institute of Curriculum and Teaching of East China Normal University, pointed out that moral education is both local and international, historical and futuristic, as well as value and education ${ }^{[3]}$. Moral education is the fundamental task of the development of education in China. It is not only an important content of education, but also the basic requirement of socialist core values. Moral education has rich and profound connotation. It does not only include the inheritance of the fine traditional thoughts of the Chinese nation, but also bring about new development in a changing world through the deepening of the education concept in the new era.

\subsection{Adhering to the principle of "moral education" is an inevitable requirement to adapt to the development and changes of education}

The world economy and society are facing unprecedented changes. The increasing flow of talents around the world is changing the way of production and life. In this context, many countries and regions are thinking about how to train people in such a way so that they can better adapt to work and life in the future. Therefore, the exploration of education reform began in order to walk at the forefront of education development. Core literacy has become a hot topic in the field of education. United Kingdom was the first country to emphasize on core literacy. In the UK, "core literacy" is interdisciplinary literacy and a basic requirement. In 2002, the United States introduced the "21st Century Skills," and European Union (EU) proposed a framework of core literacy, dividing students' core literacy into three dimensions: personal development, social integration, and economic life. In Japan, core accomplishment encompasses virtue, knowledge, and health, while in China, core literacy is defined as the essential character and key ability that students at all levels should possess to adapt to lifelong development and social development. In order to cultivate an "all-round development of people" as the core, core quality can be divided into three aspects: cultural foundation, independent development, and social participation, which are comprehensively manifested as cultural heritage, scientific spirit, learning to learn, healthy life, responsibility, practice, and innovation ${ }^{[4]}$. The proposal of core literacy will further accomplish the fundamental goal of moral education and change the phenomenon of "only score theory," which still exists in the field of education. It is the "Chinese voice" that China sends out to the world in terms of educational goals.

\subsection{Adhering to the principle of "moral education" is an inevitable requirement for inheriting the fine traditions of the Chinese nation}

The Chinese nation attaches great importance to moral education. During the period of Chinese slave and feudal societies, moral education was in the primary position in schools. Among the "six arts" (rites, music, archery, charioting, calligraphy, and mathematics) in the Western Zhou Dynasty, "rites" was placed first. Confucianism advocates "rule by virtue" and "rule by courtesy." Zuo Zhuan once mentioned, "A superior man has virtue, followed by meritorious deeds, and then words; without abandoning these, this is called immortality." This means that virtue should be first established, followed by merits, and then doctrine. Even after a long time, these would not be discarded; this is called immortality. Dong Zhongshu, a philosopher 
during the Western Han Dynasty, emphasized on "governing the country by virtue." In the implementation of moral education, the ancient sages of China emphasized on several educational methods, such as setting an example, conforming words and deeds, teaching students according to their aptitude, advocating ambition, and carrying out moral practice. Therefore, it can be appreciated that moral education is the education concept followed by all generations. Moral education does not only have a huge impact on the survival and development of individuals, but also on politics, economic, culture, and other aspects of the society.

\subsection{Adhering to the principle of "moral education" is an inevitable requirement for cultivating innovative talents with both moral integrity and ability}

Education is important in solving the issues of "who to train," "how to train," and "for whom." Moral education and education have a complementary relationship. Moral education is the soul of education. Without moral education, education would only become a tool for people to realize their own interests, and the cultivation of talents needed for social development would be non-existent. Moral education is a value that higher education must always adhere to. Shu Li, the Dean of Communication Research Institute at the Communication University of China, interpreted the connotation of General Secretary Xi Jinping's repeated emphasis on "moral education" as the fundamental task of education. She pointed out that taking moral education as the fundamental task of education should be at the higher education level. She also clarified the primacy of "ethics" in the evaluation of talents and talent training as well as pointed out the political direction and value orientation of talent training in colleges and universities ${ }^{[5]}$.

\section{Practical problems existing in moral education in colleges and universities}

\subsection{Educators' cognition of moral education affects the practical effect}

Educators are not only the essential part of educational activities, but also the subject of these activities. In the actual process, educators guide the physical and mental changes of educatees through various educational methods and approaches. Educators are designers, implementers, and organizers of educational activities; they play a leading role in educational activities. Socialist core values exert influence on educatees through educators. Therefore, the role of educators is crucial. In the implementation process of practical education, many higher education educators carry out curriculum ideological and political reform, exerting the influence of "moral cultivation" on educatees. However, in the actual implementation of ideological and political affairs, sometimes the contents of ideological and political affairs as well as the knowledge of the integration are not natural, requiring further discussions. The natural integration of the two to achieve the effect of educating people insidiously is the pursuit of moral education.

\subsection{The value orientation of educatees is affected by the social environment}

With the rapid development of the society, the pursuit of interests led by market economy has greatly influenced the values of educatees. Stepping into university, there is a lack of supervision from family and teachers, and many students lack self-learning skills as well as self-education consciousness. Facing the impact of the social environment and diversified network environment, their values may change, thus bringing huge challenges to moral education ${ }^{[6]}$. Educatees also have their own particularities. The family education and social education they received since childhood are different. This also increases the difficulty of implementing moral education in colleges and universities. Educators need to emphasize more on ideological and political content, view problems from multiple angles and levels, as well as take into account of the educatees while designing the courses and lessons, so that the educatees would not only have 
the motivation to learn, but also heal themselves as well as develop a healthy and positive attitude. The outbreak of the new crown pneumonia in 2020 has had a great impact on people's lifestyle. Compared with the response measures of other countries, China's political system has shown great advantages. This is both an opportunity and a challenge for the educated. Their outlook on life, values, and world outlook are all affected. Therefore, curriculum ideology and politics must respond to various changes in a timely manner and exert a positive influence on educatees according to the requirements of the times.

\subsection{The interactive effect of the education process of moral education in colleges and universities needs to be improved}

In teaching activities, educators and educatees interact with each other through various educational activities. The teacher-centered theory represented by Herbart and the student-centered theory represented by Dewey have not been recognized by most people through practice. The teacher-centered theory emphasizes that educational activities should be teacher-centered, which obliterates students' subjective initiative and subject status. On the other hand, the student-centered theory emphasizes that educational activities should be student-centered and obliterate the leading role of teachers in the educational process [7]. The teaching process is a process of joint activities between educators and educatees, and the law of unity between educators and educatees is an important law in teaching. The implementation of moral education in colleges and universities is mainly realized through communication between teachers and students in classrooms. In the implementation of moral education in colleges and universities, if educators transfer knowledge unilaterally while neglecting the background and values of the educatees, the lack of emotional interaction between the two would lead to a significant reduction in the effect of moral education. If educatees proceed with discussions without guidance, the effect of ideological and political thinking would be less.

\section{Exercising moral education by focusing on curriculum ideology and politics}

\subsection{Actively implementing curriculum construction focusing on ideological and political education}

The first is curriculum planning, which mainly refers to the type of courses being set up, such as college English, circuit maintenance, organic chemistry, and others. The content of each course is different, and the corresponding ideological and political content also varies. For each course, ideological and political content can be found and related to each course content. The effect of educating people is not the same; hence, appropriate ideological and political content is the best. The second is the implementation of the curriculum, which mainly solves the problem of "how to teach" in order to achieve the training goals. When establishing and developing courses based on certain ideas and theories, teachers should integrate the ideological and political ideas of the course into a guiding position; then, gradually integrate ideological and political content into the course content according to the characteristics of the students and professional requirements. Curriculum construction is a long process, requiring constant updating, continuous accumulation, as well as thinking and improving based on work experience.

\subsection{Elaborately creating a classroom teaching design with moral education first}

Teaching plan for teaching is equivalent to the foundation for architecture; its importance is self-evident. By designing teaching plans, teachers can understand the students and teaching materials better, clarify the key and difficult points in teaching, gauge the knowledge base and experience of students, as well as design a reasonable teaching process according to the characteristics of the students, so that teachers are in line with the rules and have evidence to rely on in class. If the purpose of the teaching plan is just to impart knowledge, it would be difficult to put moral education into practice. Therefore, in designing teaching plans, 
teachers should give full consideration to the reflection of political education, neither the one-way infusion of moral knowledge, nor allowing the students to gain control of the classroom. Teachers should give full play to their leading roles, respect each student's life experience, as well as guide students step by step in learning how to discern and analyze; eventually, by doing do, the educational effect of moral education would be achieved. Therefore, teachers should understand the talent training program, curriculum teaching plan, and curriculum standards as well as design teaching plans carefully, so as to achieve the best effect of moral education. The implementation of teaching plans depends on a good classroom atmosphere. Classroom atmosphere is like air, which cannot be felt at ordinary times, but humans cannot survive without it. A good classroom atmosphere refers to a positive teaching environment, in which teachers and students are equal, cooperating with each other and appreciating one another. College students are grown-ups; they have active minds and enjoy a good teaching atmosphere. In a good teaching atmosphere, teachers are in a positive emotional state, where they respect students' differences and are able to stimulate students' interest while imparting knowledge; students, on the other hand, are in an active state of thinking, having the courage to express their ideas in various situations while actively cooperating with their classmates. The key to build a good atmosphere lies in the teacher: the prestige of the teacher and the appreciation attitude of the teacher toward the students. Teachers and students come together to achieve a harmonious coexistence. Through this, students would not only gain intelligence, but also cultivate interest and exercise a sound personality, thus achieving an all-round development. Classroom atmosphere is particularly important to the success of moral education.

\subsection{Making full use of online and offline classes to innovate the ideological and political forms of courses}

Since the outbreak of the epidemic, traditional classes have suffered a great impact because students are not allowed to return to school. In this case, schools have launched online teaching, followed by the use of various teaching software, such as Yu Classroom, Xue Xi Tong, and Tencent Conference. Each software has its own advantages and brings a new experience to its users. Compared with traditional teaching, online classroom has many forms, and it is easier to attract students with various puzzles and mini games. Teachers should make full use of the advantages of online classroom to integrate curriculum ideology and politics into it as well as innovate the forms to ensure an authentic moral education in online classrooms. The combination of online and offline teaching enriches the content and innovates the form of ideological and political courses. This is a good opportunity for teachers to construct courses. One of the challenges of using online and offline hybrid teaching in carrying out curriculum ideological and political education is the innovation of classroom teaching evaluation. Classroom teaching evaluation refers to classroom evaluation activities organized by teachers for students. Its purpose is to promote the growth of students and improve the quality of teaching. The evaluation content should be timely adjusted according to the behavior of the evaluated subject. College students have relatively high requirements for evaluation, so the evaluation must be practical, realistic, accurate, and decent, yet vivid and clever. It is difficult to quantify evaluation in offline classes; hence, oral praise is the main method. Online evaluation can keep records for easy quantification, thus making curriculum ideology and politics more attractive.

\section{Conclusion}

Classrooms in colleges and universities are the main place for the implementation of moral education. Only good teachers can train up good students. Therefore, college teachers should pay attention to the construction of curriculum ideology and politics, fully grasp the essential connotation, understand the meaning of moral education, be an example for others, as well as integrate curriculum ideology and politics 
into the main curriculum. At the same time, teachers should take advantage of the classroom and follow the law of students' physical and mental development. In accordance with the laws of teaching, teachers should carefully design teaching activities and cultivate students into talents with a sound personality. This article discussed about the importance of carrying out curriculum ideology and politics from the connotation of moral education, the real questions existing in teaching, as well as the ways to solve questions through curriculum ideology and politics. However, it has limitations. Firstly, the questions lack rational analysis supported by data as they are mainly observed through teaching experience. Secondly, they are not representative because the experience is limited. More questions and solutions can be found in other aspects. Finally, the factors that influence the effect of moral education change repeatedly, so college teachers should continue in their exploration on this matter.

\section{Disclosure statement}

The authors declare that there is no conflict of interest.

\section{References}

[1] Xi J, 2016, Putting Ideological and Political Work Through the Whole Process of Education and Teaching to Create a New Situation in the Development of My Country's Higher Education. People's Daily, 01.

[2] Mao Q, 2021, A Practical Exploration of integrating Curriculum Thinking and Politics with College English Teaching - A Case study of College English Audio-visual Narration. Journal of Hubei University of Economics (Humanities and Social Sciences), 18(09): 156-158.

[3] Zhao X, 2016, Today, Why Do We Mention “Core Literacy”. People's Daily, 01.

[4] Wang E, (eds) 2020, "Moral education": Values and Methodology of Higher Education (Interpretation: Shu Li). Guangming Daily. http://topics.gmw.cn/2020-09/23/content_34214248.htm

[5] Cui Y, Chen S, 2017, Three Dimensions to See the Essential Connotation of "Moral Education". Guangming Daily, 01.

[6] Yuan C, 2020, Analysis of the Practical Problems and Countermeasures of Morality in Colleges and Universities in the New Era. Journal of Henan University of Technology (Social Science Edition), 21(06): 95-100.

[7] Liu J, 2015, "Teachers Leading and Students Main Body": Justification of a Classical Formula. Journal of Beijing Normal University (Social Sciences), (4): 25-33.

[8] Gong Y, 2019, What Should be Taught in University Classroom. University Teaching in China, (02): $37-41$. 